https://doi.org/10.32689/2708-7530-2020-3(3)-126-150

Олсйнік Дмитро Анатолійович фізична особа підприємець (дослідження і експериментальні розробки в галузі суспільних і гуманітарних наук), вул. Амосова, 23, кв. 360, м. Харків, 61176, тел.: (050) 325-53-42, e-mail: 3255342@ukr.net, https://orcid.org/0000-0002-9101-4891

\title{
ОПТИМАЛЬНЕ ПОДАТКОВЕ НАВАНТАЖЕННЯ, ОПТИМАЛЬНИЙ РОЗПОДІЛ ПОДАТКОВОЇ НАВАНТАЖЕННЯ: ТЕОРІЯ, МЕТОДОЛОГІЯ І ІМПЛЕМЕНТАЦІЯ В ЕКОНОМІКУ УКРАЇНИ
}

Анотація. Низькі темпи економічного розвитку України, інвестиційна непривабливість, високий рівень тіньової економіки - все це результат не тільки корупції, а й недосконалості податкової системи. Без ефективної податкової системи, яка об'єднує в собі оптимальне податкове навантаження i його оптимальний розподіл серед платників податків, неможливі ні адекватне загальносвітовим тенденціям економічне зростання, ні заняття Україною конкурентної позиції серед економік світу.

У даній роботі вперше представлена модель визначення оптимального податкового навантаження, підгрунтям якої є поведінкова модель бажання суб'єкта інвестувати кошти в офіційну економіку при заданому податковому навантаженні.

В рамках концепції оптимального розподілу податкового навантаження представлені принципово нові механізми в оподаткуванні окремих видів доходів і операцій, а саме:

- при оподаткуванні дивідендів - включення в сукупний дохід Власника прибутку Корпорації i коректировка податку на доходи Власника відповідно сплаченому Корпорацієй податку на прибуток;

- модель системи прогресивного оподаткування, що забезпечує такий перерозподіл доходів, при якому досягається певний рівень споживання («прожитковий мінімум», «обсяг мінімального споживання» і т.п.) найменш дохідних груп населення i зростання споживання низькодохідних груп, при цьому не змінюється податкове навантаження на економіку в цілому;

- кореляція податку на прибуток Корпорації та податкового навантаження на фонд оплати праці, що забезпечує і декларування заробітної плати в повному обсязі, і неможливість знизити суму сплачуваних Корпорацією податків за рахунок декларування заробітної плати;

- диференціація ставок ПДВ в оподаткуванні зовнішньоторговельної діяльності та транскордонного руху капіталів, що забеспечує зростання доданої вартості в економіці. 
Представлені розробки лягли в основу концептуальної моделі податкової системи, яка об'єднує в собі і оптимальне податкове навантаження і оптимальний його розподіл

Ключові слова: оподаткування, податкове навантаження, прогресивне оподаткування, податкова система, податкові принципи, макроекономічна модель.

Olieinik Dmitry Anatolyevich Entrepreneur (research and experimental development in the field of social and human sciences), Amosova str., 23, apt. 360, Kharkov, 61176, tel.: (050) 325-53-42, e-mail: 3255342@ukr.net, https:// orcid.org/0000-0002-9101-4891

\section{THE OPTIMAL TAX BURDEN, THE OPTIMAL TAX BURDEN'S DISTRIBUTION: THEORY, METHODOLOGY AND IMPLEMENTATION TO THE UKRAINE'S ECONOMY}

Abstract. Low economic development rates in Ukraine, investment unattractiveness, a high informal economy's part are the result of not only corruption, but also the imperfections of the tax system. Without an effective tax system combining the optimal tax burden and its optimal distribution among taxpayers, neither adequate to global trends economic growth, nor Ukraine's occupation of a competitive position among the world's economies are possible.

A model determining the optimal tax burden's value, which is based on the behavioral model of a subject's desire to invest in the official economy with a given tax burden is presented for the first time.

In the framework of the optimal tax burden redistribution's concept, fundamentally new mechanisms into the taxation of certain types of income and operations are introduced, namely:

- taxation of dividends - the Owner's aggregate income inclusions the Corporation's profit and adjustment of the income tax of the Owner in accordance with the income tax paid by the Corporation;

- the progressive tax system's model ensures such income's redistribution of at which the least income groups of the population have a certain level of consumption ("subsistence minimum", "minimum consumption", etc.) and an increase in consumption of low income groups is achieved, while the tax burden on the economy as a whole;

- correlation between the corporation's income tax and the tax burden on the payroll fund, which ensures both the declaration of wages in full and the inability to reduce the amount of taxes paid by the Corporation by declaring wages;

- differentiation of VAT rates in taxation of foreign trade activities and crossborder capital flows, which ensures the growth of value added in the economy.

The presented innovations formed the basis of the tax system's conceptual model, combining both the optimal tax burden and its optimal distribution.

Keywords: taxation, tax burden, progressive taxation, tax system, tax principles, macroeconomic model. 
Постановка проблеми. Тема «реформування податкової системи» не сходить 3 порядку денного України. Низькі темпи економічного розвитку, хронічний дефіцит бюджету і його покриття за рахунок зовнішніх запозичень, інвестиційна непривабливість, високий рівень тіньової економіки - все це результат не тільки корупції, а й недосконалості податкової системи.

Проблемних зон в податковій системі України чимало: тут і кількість податків і зборів, і певна складність обчислення тих чи інших податків, і перманентний процес внесення змін до податкового законодавства; разом з тим, головними були і залишаються «податкове навантаження і його розподіл серед платників податків»

Прийнята напочатку концепція максимізації оподаткування бізнесу [1], яка:

великому бізнесу практично не залишала коштів для технічного переозброєння виробництва (ступінь зносу основних засобів в період з 2010-2014 p.p. зросла 3 43,7\% до 83,5\% [2]), яке на сьогодні неможливо без кредитної підтримки;

дрібний i середній бізнес виштовхнула в «тінь» (за даними Київського міжнародного інституту соціології в 2018 році рівень тіньової економіки в Україні склав 47,2\% від загального обсягу ВВП і 46,8\% в 2017 році [3]), - декларування доходів і відповідно сплата всіх податків в умовах конкурентної боротьби 3 великим бізнесом і імпортом означала фактично «збитковість» діяльності;

обмежувала участь іноземних інвесторів, - інвестиції вкладалися в галузі, які не потребують великих капітальних вкладень в засоби праці: мобільний зв'язок, банки, страхові компанії, торгові мережі та т. п. (питома вага інвестицій в промисловість становила 42,2\% в 2010 р і зменшилась до 33,4\% в 2017 р [4]) мала своїм наслідком:

- розвиток галузей 3 низькою часткою доданої вартості (висока частка обумовлювала високе податкове навантаження, і не в останню чергу на заробітну плату), що мають певні пільги з оподаткування, в першу чергу по ПДВ: сільське господарство та переробка сільськогосподарської продукції, експорт сировини і напівфабрикатів ( металопрокат, продукція хімічної промисловості тощо);

- цінову неконкурентність вітчизняної готової продукції та лобіювання бізнесом реалізації даної продукції або через «освоєння» Державного бюджету, або через заняття монопольного положення на ринку;

- домінування торгівлі в структурі ВВП, як галузі, що має високу оборотність коштів i низькі витрати в частині доданої вартості; при цьому, платоспроможний попит населення підтримувався за рахунок зовнішніх запозичень;

- високий рівень тіньової економіки;

- низький рівень інвестиційної привабливості.

Застосування відмінних від базової та економічно необгрунтованих ставок $\mathrm{i}$ пільг до окремих видів доходів (єдиний податок, податок на дивіденди, податок на дохід від продажу рухомого та нерухомого майна, податок на спадщину і. П.), а також відсутність системи непрямого адміністрування доходів, привели до використання різних, як легальних, так і нелегальних, схем зниження податкового 
навантаження (переклад частини бізнесу на єдиний податок, не декларування за домовленістю 3 контрагентом частини доходів і т.п.), що, в свою чергу, призвело до зниження дохідної частини державного бюджету i покриття дефіциту за рахунок зовнішніх і внутрішніх запозичень.

Неефективне податкове регулювання зовнішньоекономічної діяльності (ставки, база оподаткування ПДВ при експорті/імпорті товарів і послуг, оподаткування транскордонного руху капіталів) деструктивно впливало на конкурентоспроможність і інвестиційну привабливість національного бізнесу.

Все це значною мірою сприяло деградації економіки України від технологічною в 90-х р.p. ХХ століття до неконкурентною сировинної в 2010-х.

Аналіз останніх досліджень та публікацій. Проблема оптимальності податкової системи не нова і виникла одночасно з появою податків.

На ранніх етапах розвитку суспільства (рабовласницький лад, феодалізм) «оптимальність» сприймалася як знаходження компромісу між державними, в сукупності з меркантильними можновладців, інтересами і протестними настроями підданих (як казав міністр фінансів Франції XVII століття Жан-Батист Кольбер: «Оподаткування - це мистецтво обскубувати гусака так, щоб отримати максимум пір'я з мінімумом писку »).

У період переходу від аграрного суспільства до промислового, становлення приватної власності на засоби виробництва і підприємництва «оптимальність» - це вже мінімізація податкового навантаження: високі податки стримують підприємницьку ініціативу i гальмують політику інвестування, оновлення та розширення виробництва. Засновники класичної політичної економії Адам Сміт i Давид Рікардо (що жили в той час) в своїх працях зазначали, що «немає податків, які не гальмували б накопичення, оскільки немає жодного податку, який би не заважав виробництву» $\mathrm{i}$, що «від зниження податкового тягаря на платників податків держава виграє більше, ніж від посилення податкового навантаження ».

Кристалізація капіталізму в системі суспільних відносин зумовила виникнення нових концепцій в економічній теорії (маржиналізм, неокласична економічна теорія). Зміщення акцентів від «розвиток конкретного виробництва» до «розвиток економіки в цілому» змінило і точку зору на «оптимальність»: податки розглядалися як один з інструментів досягнення рівноваги попиту та пропозиції $\mathrm{i}$ «оптимальність» - це не тільки величина, але і розподіл. Принципом оптимальності стає також прогресивність в оподаткуванні. Ідею прогресивності відстоюють такі відомі економісти того часу, як Кнут Вікселль, Джон Стюарт Мілль, Артур Пігу, Адольф Вагнер і ця ідея знайшла широке застосування в податкових системах усіх економічно розвинених країн.

Процес глобалізації, що отримав у другій половині XX століття потужний технологічний імпульс до розвитку і тяжіє понині над усіма економіками світу поставив перед національними податковими системами нові завдання:

- $з$ одного боку, підтримка національного виробника, створення умов для залучення іноземних інвестицій припускають мінімізацію податкового навантаження;

- 3 іншого боку, високі соціальні стандарти в боротьбі за трудові ресурси, фінансування науки, що стала в сучасному світі визначальним фактором 
конкурентоспроможності національної економіки, неможливі без наявності у Держави достатнього обсягу фінансових ресурсів - і чим він більший, тим вище соціальні стандарти, тим більше виділяється коштів на фінансування науки. А це вже максимізація податкового навантаження.

I сьогодні «оптимальність» - це перерозподіл доходів, максимально стимулюючий економічне зростання (оптимальний розподіл податкового навантажсення), при цьому податкове навантаження на бізнес повинне максимізувати надходження до Державного бюджету (оптимальне податкове навантажсення), що означає створення таких важелів і стимулів, при яких бізнес розвивається i цей розвиток має місце в легальному секторі економіки (детінізація).

Залежність між податковим навантаженням і податковими надходженнями вивів ще в 70-х роках XX століття американський економіст Артур Лаффер, який побудував знамениту криву Лаффера. Концепція кривої має на увазі наявність оптимального рівня оподаткування, при якому податкові надходження досягають максимуму, тобто збільшення податкового навантаження спочатку призводить до збільшення бюджетних доходів від податків, але після певного рівня призводить до їх падіння. Однак ні сам Артур Лаффер, ні його послідовники не змогли виробити модель визначення оптимального значення 3 позиції економікоматематичної логіки i намагалися знайти оптимум емпіричним шляхом, зіставляючи податкове навантаження 3 темпами зростання ВВП. Разом 3 тим, стійкого зв'язку між податковим навантаженням i економічним зростанням виявлено не було. Згодом дана концепція використовувалася переважно в якості одного з елементів більш загальних економіко-математичних моделей і в даний час економічна наука в цілому досить критично налаштована до концепції кривої Лаффера. Деякі автори вважають, що крива Лаффера не більше ніж гіпотеза, інші перевіряють iі емпірично. Існує думка, що дана закономірність не носить загального характеру, але має місце при певних умовах.

Також немає єдиної думки в питанні розподілу податкового навантаження. Прихильники теорії пропозиції наполягають на мінімізації податкового навантаження на бізнес і власників бізнесу (відмова від прогресивного пропозиції), обгрунтовуючи це тим, що зниження податкового навантаження стимулює інвестиційні процеси, тим самим, збільшує пропозицію товарів і послуг і знижує їх ціну. Противники цієї теорії вважають, що, навпаки, попит породжує пропозицію, а стимулювання попиту - це перерозподіл доходів найбільш забезпечених громадян на користь менш забезпечених.

I питання оптимальності податкового навантаження та податкового перерозподілу доходів економіки залишаються на сьогодні відкритими.

Свій внесок в дослідженні теоретичних і практичних аспектів підвищення ефективності оподаткування привнесли і українські вчені. Теоретичні основи i практичні аспекти податкового регулювання, а також проблеми податкового реформування знайшли своє відображення в працях українських вчених В. Андрущенко, 3. Варналія, І. Волохова, Т. Сфименко, І. Запатріної, В. Зимовця, А. Крисоватого, В.Кудряшова, I. Луніної, I. Петровича, Л. Рябушки, А. Соколовської, Л. Тарангул, І. Чугунова та ін. 
Однак, з огляду на сучасні реалії і в економіці України в цілому, і в сфері оподаткування зокрема, можна зробити висновок про те, що даний напрямок дослідження вимагає подальшої доробки і розробки з метою удосконалення.

Мета статті - модель визначення оптимального значення податкового навантаження, механізми оптимального його розподілу, модель податкової системи, яка об'єднує в собі і оптимальне навантаження і оптимальний розподіл на цьому сфокусована і цьому присвячена ця стаття.

\section{Виклад основного матеріалу.}

\section{Оптимальне податкове навантаження.}

у спробах знайти оптимальне значення податкового навантаження дослідники, як правило, розглядали податкове навантаження 3 висоти макроекономічного аналізу, не опускаючись до рівня поведінкової економіки. Але, слід розуміти, що економіка, на відміну від фізики, не настільки об'єктивна i економічні процеси багато в чому підпорядковані перевагам, бажанням, рішенням економічних суб'єктів. А це означає, що і в визначенні оптимального значення, на думку автора, потрібно виходити 3 бажання власника бізнесу платити чи не платити податки (вести бізнес в легальній економіці) при заданому рівні податкового навантаження. В рамках даної концепції знаходження оптимального значення здійснюється в три етапи:

1. Побудова моделі бажання суб'єкта інвестувати кошти в офіційну економіку при заданому податковому навантаженні.

2. Побудова моделі залежності податкових надходжень від податкового навантаження на підставі моделі бажання.

3. З Знаходження значення податкового навантаження (оптимум), при якій податкові надходження досягають максимуму.

Податкове навантаження в моделі - це процентне співвідношення суми сплачених податків (в тому числі і податків на дохід найманих працівників) i прибутку (до оподаткування) платника податків.

\section{1. Модель бажсання суб'єкта інвестувати кошти в офіційну економіку при} заданій податковому навантаженні базується на таких постулатах.

- очікуваний дохід (після сплати податків) повинен бути не менше доходу за банківськими депозитами або першокласними цінними паперами, в іншому випадку доцільні або інвестиції в депозити / ЦБ, або ухилення від податків;

- при прийнятті рішення інвестувати кошти в реальний сектор економіки суб'єкm орієнтується на середні / середньогалузеві показники рентабельності капіталу;

- в залежності від величини податкового навантаження бажання суб'єкта змінюється від відмови до повної готовності. У графічному поданні це виглядає як плавний перехід з горизонтального вектору руху (відмова) в вертикальний (повна готовність).

Кривій плавного переходу горизонтального напрямку руху в вертикальне i навпаки є еліпс (будь-яка інша крива не відповідатиме вимогам «природного» плавності) i, якщо в прямокутній системі координат:

а) вісь OX - це рівень (у відсотках) бажання суб'єкта; 
б) вісь OY - податкове навантаження (у відсотках) на очікуваний дохід від інвестицій, то це буде нижній лівий сектор еліпса (див. мал.1), в якому

а) вертикальна піввісь дорівнює 100;

б) горизонтальна піввісь - також, виходячи з економіко-математичної логіки, повинна б бути рівною 100, але ... вкладенням в реальний бізнес існує альтернатива у вигляді вкладень у депозити / ЦБ, і бажання суб'єкта інвестувати кошти в реальний сектор економіки і, відповідно, платити податки варіюється в межах від «ефективність вкладень у депозити / ЦБ» до «ефективність в реальному секторі економіки».

Таким чином, довжина горизонтальної півосі визначається формулою:

$$
\begin{aligned}
& a=(100-\Delta a) \\
\Delta a= & \frac{R_{f}}{R_{e}} * 100
\end{aligned}
$$

де,

$R_{f}$ - рентабельність (після оподаткування) за банківськими депозитами або першокласними цінними паперами;

$R_{e}$ - середні по економіці в цілому, за винятком фінансового сектора (середньогалузеві, якщо об'єктом регулювання є конкретна галузь економіки) показники рентабельності (до оподаткування) капіталу

Базовою формулою, що описує функціональну залежність між рівнем бажання (за шкалою [0-100]) і податковим навантаженням, буде:

$$
f m_{i}=-\sqrt{\left(1-\frac{\left(-a+m_{i}\right)^{2}}{(a)^{2}}\right) * 10000}+100
$$

де,

$f m_{i-}$ рівень бажсання інвестувати кошти в офіційну економіку при ті податковому навантаженні

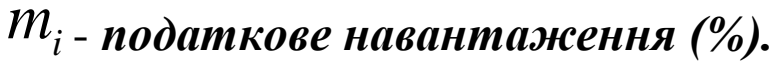

Крива бажання, досягнувши нульового значення, переходить в криву «антибажання» (див. Мал.1), яка також має еліпсоподібну форму. Але це має інтерес тільки 3 теоретичної точки зору, тому що, якщо чиста (після оподаткування) рентабельність капіталу нижче рентабельності по банківських депозитах, то реальний сектор економіки або перестає працювати, або повністю іде «в тінь». 


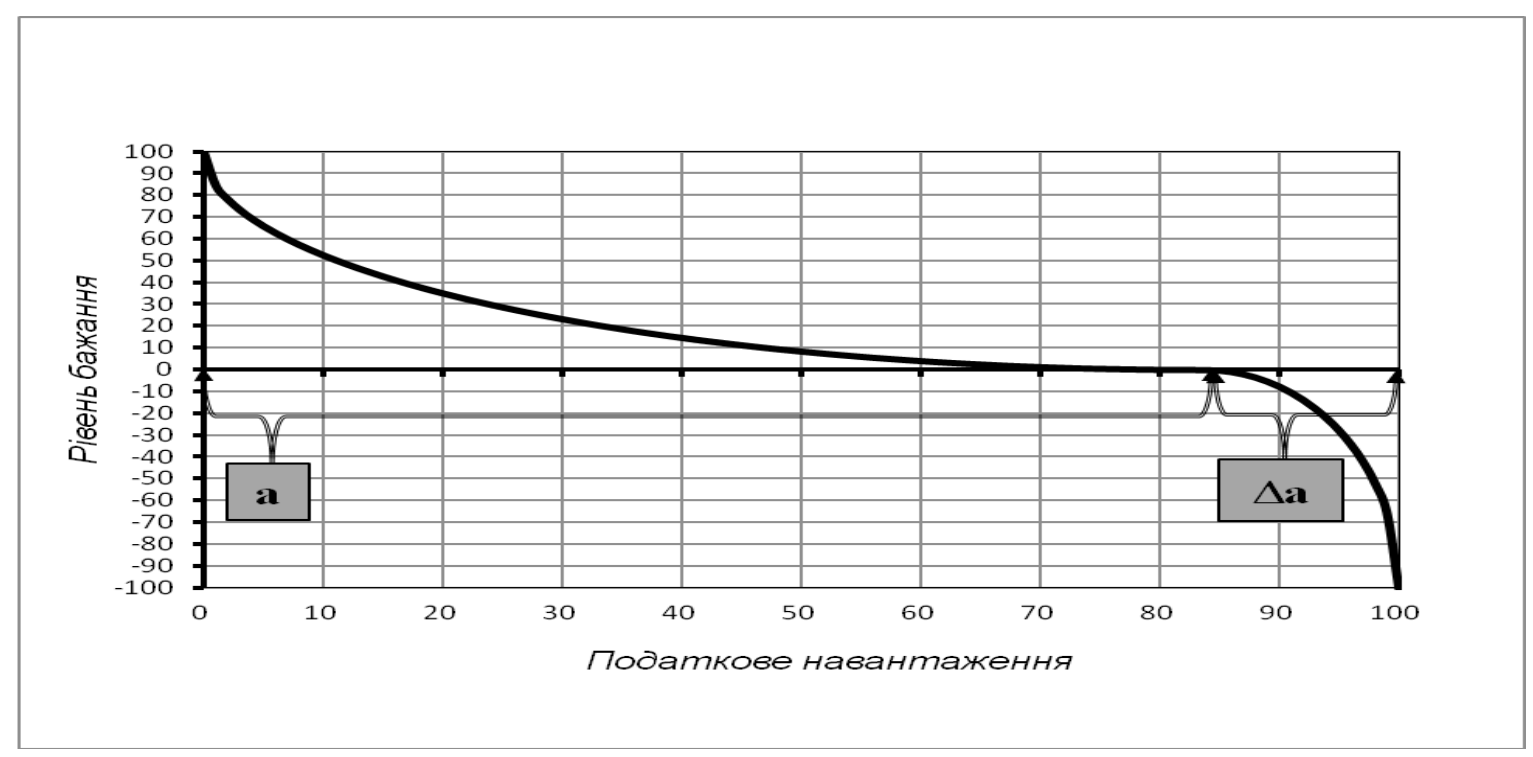

Мал. 1. Крива бажання суб'єкта інвестувати кошти в офіиійну економіку при заданлму податковому навантаженні

Коли доходи по депозитах/ЦБ не оподатковуються за фіксованою ставкою, а включаються до розрахунку загального оподатковуваного доходу, 3 ростом податкового навантаження знижується рентабельність вкладень у депозити/ЦБ і підвищується рівень бажання суб'єкта інвестувати кошти в реальний сектор економіки (з ростом податкового навантаження зменшується $\Delta \mathrm{a}$ ). У моделі бажання це буде перехід від константи « $\Delta а$ » до мінливої зі зміною податкового навантаження «ті» величини « $\Delta$ аі»:

$$
\Delta a_{i}=\frac{R_{f} *\left(100-m_{i}\right) / 100}{R_{e}}
$$

відповідно, константа « $a »$ стає « $a_{i} »$

$$
a_{i}=\left(1-\Delta a_{i}\right) * 100
$$

і формулою, що описує залежності між рівнем бажання і податковим навантаженням, $\epsilon$

$$
f m_{i}=-\sqrt{\left(1-\frac{\left(-100+a_{i}+m_{i}\right)^{2}}{\left(a_{i}\right)^{2}}\right) * 10000}+100
$$

Крива бажання втрачає свою строго еліпсоподібну форму і в прив'язці до показників економіки України за 2019 рік (рентабельність капіталу - 55\% [5]), рентабельність по банківських депозитах - 8,9 \% [6]) має вигляд кривої «А» на мал. 2

2. Модель залежності податкових надходженнь від податкового навантаження 
Екстраполюючи рівень бажання на підприємницьки оріснтовану частину населення 3 повною підставою можна стверджувати, що рівень бажання - це фактично питома вага суб'єктів, які бажають використовувати інвестований капітал в офіиійній економіці в загальній кількості власників бізнесу. Тому, податкові надходження в даному контексті - це добуток значень моделі бажання на значення податкового навантаження.

$$
R_{i}=f_{m_{i}^{*}}^{*} x_{i}
$$

$f_{m_{i}}$ - рівень бажсання при податковому навантаженні, рівному $X i$

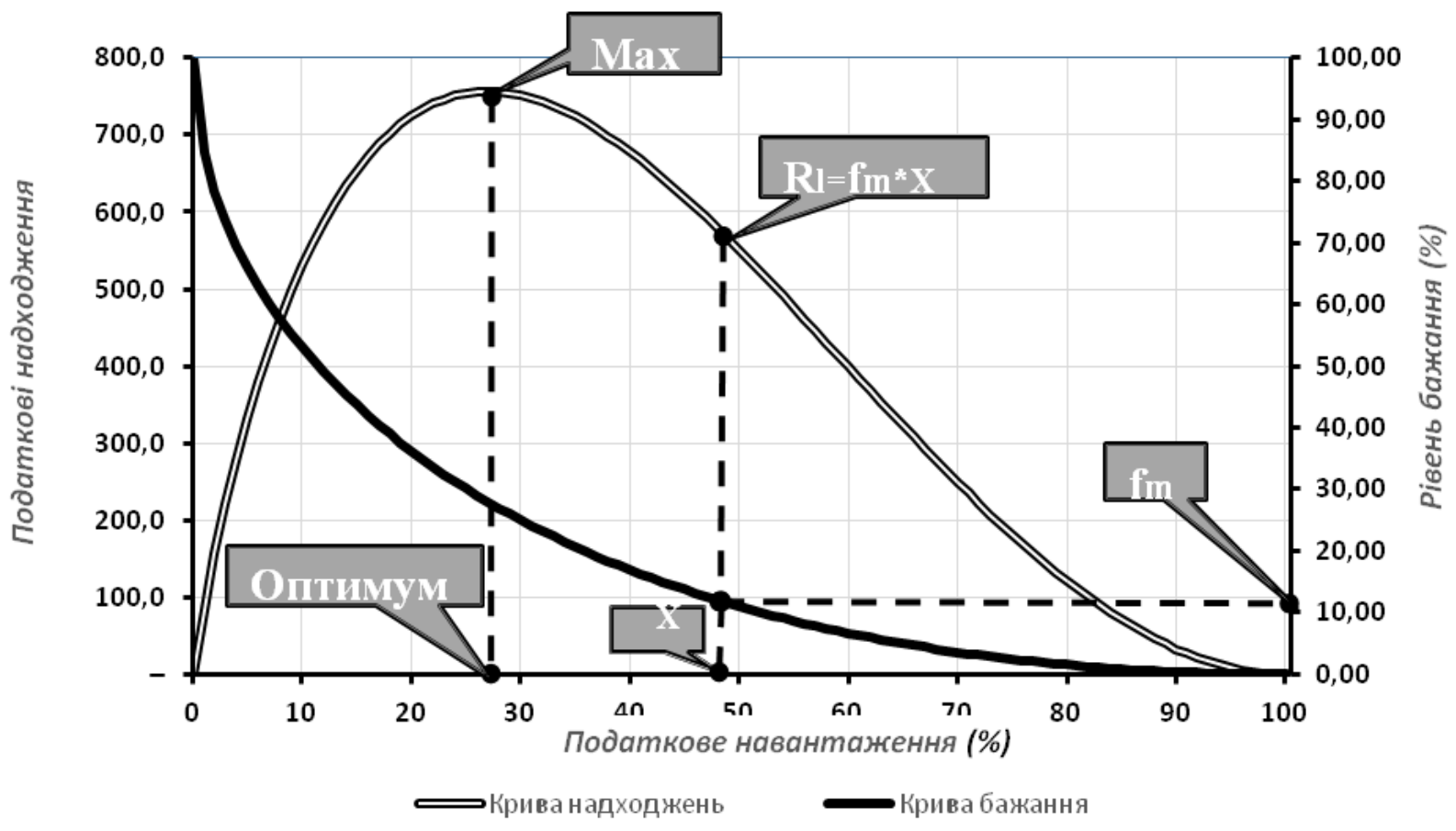

Мал. 2. Податкові надходження в залежності від податкового навантаження.

3. Оптимальним буде значення, при якому крива податкових надходжень досягає свого максимуму.

В 2019 році (за даними річного звіту про виконання Державного бюджету України за 2019 [7]) базове податкове навантаження на доходи бізнесу (включаючи податки на дохід найманих працівників) в Україні склало 43,7\%, - як видно 3 мал.2, максимальний обсяг податкових надходжень досягається при податковому навантаженні в $27 \%$.

Звісно, даний розрахунок не претендує на абсолютну точність - в економіці України істотну частку займає державний сектор, який не завжди, і не в усьому підпорядковується законам ринку і який не виділяється в окрему категорію в офіційній статистиці, - але те, що, податкове навантаження в Україна вище 
оптимального, його зниження призводить до детінізації економіки наочно демонструє динаміка реального ВВП, обсяг якого визначається на підставі статистики задекларованих доходів, у посткризовий (мається на увазі світову фінансову кризу 2008 року) період, коли нівелювалося вплив на зростання ВВП кредитів від нерезидентів.

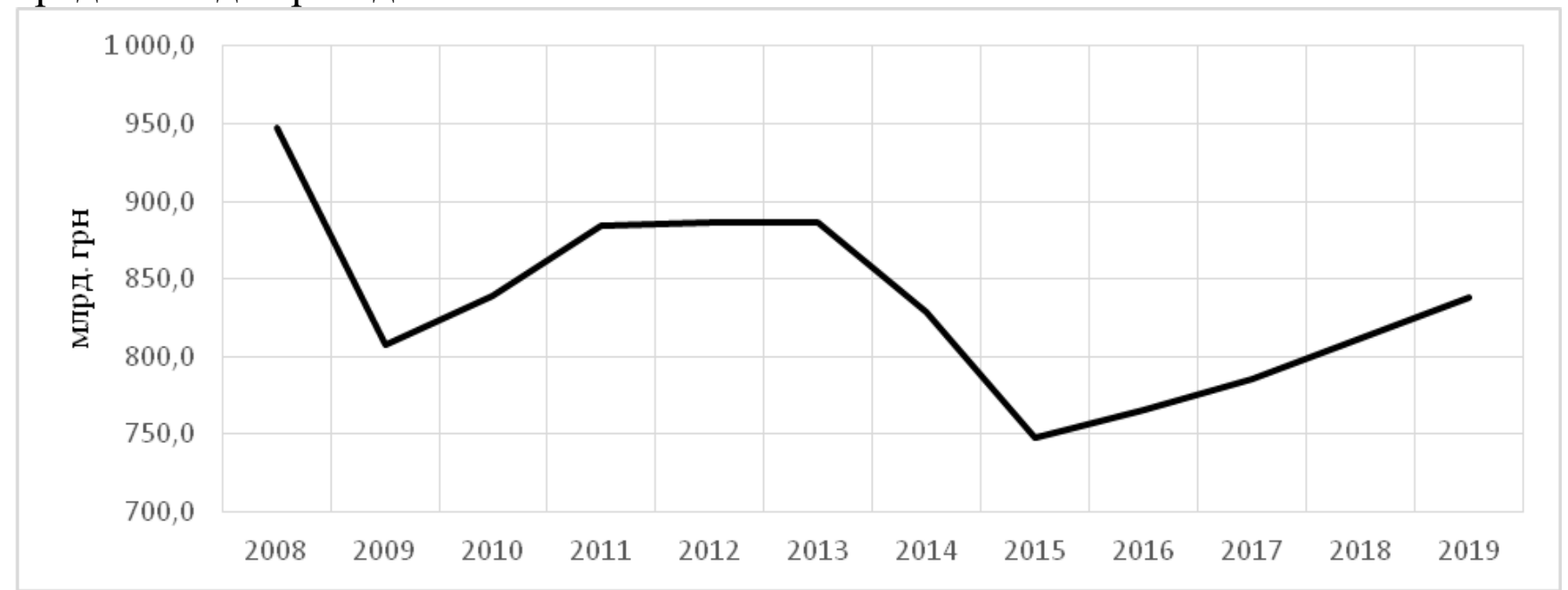

Мал 3. ВВП в постійних иінах 2008 року [8]

2010 р. Анонсування зниження протягом 4 років податку на прибуток до 16\% - зростання ВВП на 3,8\%. Справедливості заради слід зазначити, що таке істотне зростання в певній мірі пов'язано з масштабними податковими перевірками бізнесу 3 відповідними донарахуваннями податкових зобов'язань, що мали місце в той час.

2011 р. Зниження ставки податку на прибуток з 25\% до 23\% - зростання ВВП на $5,5 \%$.

2012 р. Зниження ставки податку на прибуток з 23\% до 21\% - незначне зростання ВВП на 0,2\%, проте необхідно враховувати суттєве зростання ВВП в 2010-2011 p.p.

2013-2014 р.p. Падіння ВВП, але це не має відношення до податкового навантаження, а пов'язано з політичними процесами в Україні

2015 р. - Введення з серпня 2014 р військового збору (1,5\% на ФЗП) - падіння ВВП на 9,8\%;

2016 р. Зниження податкового навантаження на заробітну плату на 12,76\% (зниження ставки ССВ 3 37,76\% до 22\% і підвищення ПДФО на 3\%) - стійке зростання ВВП в 2016-2019 рр. на 11,3\%

Безумовно, певний вплив на декларування доходів мали і кон'юнктура ринку продукції, що експортується (відшкодування ПДВ покриває витрати українських експортерів на сплату податків), і рівень активності контролюючих органів, i історично сформована культура сплати податків, але провідна роль була i залишається за податковим навантаженням.

Додатковим ефектом від зниження податкового навантаження (не можна не відзначити: i корупційного навантаження на бізнес, яке де-факто знижує рентабельність капіталу) буде зростання інвестиційної привабливості України, що означає - і зростання ВВП, і відповідне зростання податкових надходжень. 
Разом 3 тим, знаходження оптимального значення податкового навантаження на бізнес ще не вирішення проблеми оптимальності - система оподаткування повинна бути побудована таким чином, щоб оптимальна ставка застосовувалася до сукупного доходу економіки. I для цього потрібні спеціальні механізми оподаткування окремих видів доходів і оподатковуваних операцій.

\section{Розподіл прибутку підприємств, організацій, установ (далі по тексту}

\section{"Корпорацій»)}

У сформованій на сьогодні концепції суб'єктом оподаткування прибутку/доходу визнається номінальний власник цих доходів. Виходячи 3 суб'єктності, визначені три групи доходів, як об'єкта оподаткування:

- доходи фізичних осіб;

- прибуток корпорацій;

- доходи нерезидентів.

Податкова база по кожному об'єкту визначається окремо, не корелюючи 3 базами по інших об'єктах.

I начебто все виглядає логічно і не викликає сумнівів у правильності даного підходу: корпорації отримали прибуток - сплатили податок, фізособи/нерезиденти отримали дохід - сплатили податок

Але, Корпорація апріорі є чиєюсь власністю і прибуток, що утворюється в Корпорації, фактично належить Власникам.

Більш того, прибуток Корпорації - це результат інвестування Власниками в Корпорацію фінансових, матеріальних, інтелектуальних і т.п. ресурсів, а також управлінських рішень Власників (визначення стратегії, призначення топменеджменту i т.п.) А це означає, що податок на прибуток сплачений Корпорацією - це фактично авансовий платіже з податку на доходи Власників і за фактом розподілу прибутку Корпорації, в базу оподаткування Власника (сукупний дохід) треба включати прибуток до оподаткування, при цьому розрахункова сума податку на доходи Власника зменшується відповідно сплаченому Корпорацією податку на «цей розподілений» прибуток. Тобто, коли частиною сукупного доходу Власника $є$ в тому числі і доходи від розподілу прибутку Корпорації, сума податку на доходи Власника визначається за формулою:

$$
T_{\text {own }}=\left(I n_{\text {oth }}+P_{c o} * S h_{o w n}\right) * T R_{o w n}-C T * S h_{o w n}
$$

де,

$T_{\text {own - сума податку; }}$

In ${ }_{\text {oth }}$ - доходи, відмінні від доходів від розподілу прибутку Корпорації;

$\boldsymbol{P}_{\text {co }}$ - прибуток Корпораціі;

$S h_{\text {own }}$ - частка Власника в капіталі Корпорації;

$T \boldsymbol{R}_{\text {own }}$ - ставка податку на доходи фізичних осіб (для прогресивного оподаткування, відповідно, розрахункова ставка); 
$C T$ - податок на прибуток, сплачений Корпорацією;

У ситуачїі, коли виникає необхідність стимулювання розвитку тієї чи іншої галузі, Корпорачіiі і т.п., до прибутку Корпорації застосовується знижена ставка податку, однак при розрахунку суми податку на доходи Власника (Тошп) податок на прибуток, сплачений Корпорачією (СТ) визначаються не за фактом, а як розрахункова, в застосуванні стандартної ставки, величина; відповідно, знижується податкове навантаження на Власника./

І цей механізм:

•по-перше, перенаправляє вектор суб'єктності оподаткування 3 «Інструмент отримання доходу» (Корпорація) на «Ініціатор і кінцевий бенефіціар даних доходів».

•по-друге, дотримується принципу рівності і справедливості, згідно з яким «платники податків з однаковими доходами повинні сплачувати податок за єдиною ставкою»;

- по-третє, в застосуванні 3 оптимальною прогресивною ставкою, центрує економіку навколо середнього бізнесу - власники бізнесу «нижче середнього» оподатковуються за зниженими ставками і тим самим стимулюється розвиток їх бізнесу, в свою чергу, власники бізнесу «вище середнього» оподатковуються за більш високим ставками, і тим самим розвиток їх бізнесу сповільнюється.

У проекції на податкову систему України задіяння даного механізму, за умови застосування прогресивної ставки до доходів Власників, i буде податком на виведений капітал.

\section{Прогресивне оподаткування.}

Сьогодні система прогресивного оподаткування використовується практично у всіх розвинених країнах світу; вважається, що дана система $є$ соціально справедливою, так як обумовлює перерозподіл податкового тягаря в бік багатих. Разом 3 тим, якщо соціальна компонента не піддається сумніву, питання параметрів прогресивного оподаткування (шкала доходу, ступінь зростання податкової ставки, ii максимальне значення) залишаються дискусійними. Приймаючи рішення про зміну тих чи інших параметрів, уряди, як правило, виходять 3, або майбутнього зростання витрат бюджету, або, навпаки, можливості зниження податкового навантаження на фізичних осіб. Такий підхід обумовлений тим, що прогресивна система оподаткування розглядається виключно з соціальної точки зору: «багаті повинні платити більше; а наскільки більше - залежить від стану бюджету». При цьому не приділяється належної уваги головній економічній складовій - перерозподіл частини доходу більш забезпечених верств населення на користь менш забезпечених зумовлює зростання обсягу споживання в економіці (умовно, замість одного батона, придбаного щодня однією багатою людиною, за рахунок перерозподілу купується 10 батонів); як наслідок: додаткові податкові надходження за рахунок зростання обсягів реалізації i, звісно, зростання ВВП.

Тому, в питанні «використовувати, чи не використовувати прогресивну ставку оподаткування?» необхідно дотримуватися принципу економічного прагматизму: оподаткування має забезпечити такий перерозподіл доходів, при якому досягається певний рівень споживання («прожитковий мінімум», «обсяг мінімального 
споживання» i т.п.) найменш дохідних груп населення i зростання споживання низькодохідних груп. При цьому оптимальним буде «перерозподіл», який не змінює податкове навантаження на економіку в цілому.

Тобто система прогресивного оподаткування повинна відповідати таким основним вимогам:

- доходи, нижчі прожиткового мінімуму, звільняються від оподаткування;

- динаміка приросту ставки відповідає динаміці приросту доходів;

- обсяг доходів Державного бюджету від застосування підвищеної ставки оподаткування має дорівнювати сумі додаткових витрат на соціальне забезпечення груп населення, що мають доходи нижчі «прожиткового мінімуму» і збитків від застосування знижених ставок;

I визначення параметрів прогресивного оподаткування - це рішення наступної математичної моделі.

$$
\sum_{i=f m+1}^{i \max }\left(\operatorname{In}_{i} * T R_{i} * Q_{i}\right)=\sum_{i=1}^{i \max }\left(\operatorname{In}_{i} * T R_{o p t} * Q_{i}\right)+V_{\text {sub }}
$$

де,

i - розподіл шкали доходу на групи;

$f m$ - порядковий номер групи доходів, рівних прожиткового мінімуму

$\boldsymbol{I n}_{\boldsymbol{i}}$ - річний дохід до оподаткування для і-ї групи;

$T R_{i}$ - ставка податку для і-ї групи;

$T R_{o p t}$ - оптимальна податкове навантаження;

$Q_{i}$ - чисельність людей, які отримують доходи і-ї групи;

$i$ max - порядковий номер групи максимальних доходів (остання за шкалою);

$V_{s u b}$ - різниця між сукупним річним доходом (до оподаткування) людей, що мають доходи нижче прожиткового мінімуму, і сукупним річним доходом, який ці люди повинні мати, отримуючи дохід у розмірі прожиткового мінімуму (субсидії)

$$
V_{s u b}=\sum_{i=1}^{f m}\left(F M-I n_{i}\right) * Q_{i}
$$

де,

$\boldsymbol{F M}$ - прожитковий мінімум;

Рішенням даної моделі буде область значень ставки податку Tri, динаміка приросту якої відповідає динаміці приросту доходів $I n_{i}$

Розглянемо, як перерозподіляються доходи населення в застосуванні даної моделі прогресивного оподаткування (див. мал.5) 


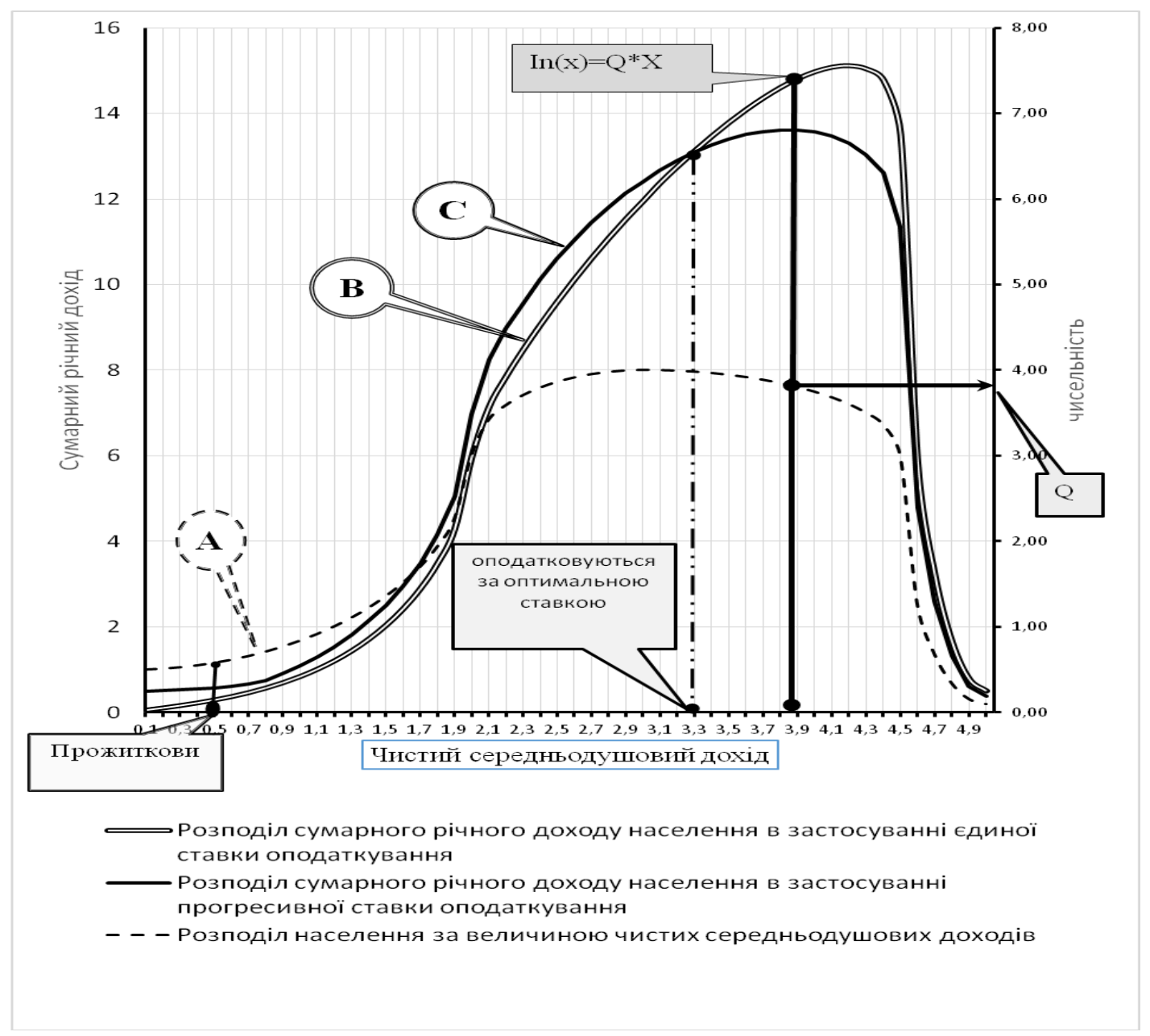

Мал. 4. Прогресивне оподаткування.

Припустимо, що розподіл населення за величиною чистих (в застосуванні єдиної ставки податку 30\%) середньодушових доходів на рік (\$) має вигляд кривої «A»

Відповідно, сумарний річний дохід людей з чистими доходами, рівними значенням $\mathrm{X} \epsilon$ добутком значення $\mathrm{X}$ і значення Y відповідної точки даної кривої. Таким чином, розподіл сумарного річного доходу населення в застосуванні єдиної ставки оподаткування має вигляд кривої «В». Площа криволінійної трапеції обмеженою даної кривої буде річним чистим доходом населення (сукупний річний дохід).

Припустимо, що прожитковий мінімум дорівнює 1 (при ставці 30\% податку це відповідає чистими доходами рівним 0,7). Результатом застосування прогресивної ставки податку є зміна розподілу сумарного річного доходу населення (на графіку - це крива «С») при якому:

1. Точка перетину кривих «С» $\mathrm{i}$ «В» $е$ «осьовою» розподілу сумарного річного доходу населення в застосуванні єдиної ставки податку - площі криволінійних трапецій, обмежених кривою В для $X=[0,1 ; 3,25]$ і для $X=[3,25 ; 5]$ рівні. 
2. Для найменш дохідних груп населення (X $=[0,1 ; 0,7])$ за рахунок субсидування (Vsub) рівень доходу піднімається до прожиткового мінімуму - криві «C» $i$ «B» зближуються, $i$ в точи̧і $X=0,7$ відрізняються на величину сукупного податку на доходи, який сплачувала б група населення 3 доходом «1» 6 застосуванні єдиної ставки оподаткування.

3. Збільшується сукупний чистий дохід менш забезпечених (до «серединних») верств населення. Причому в міру наближення доходів до «серединних» ступінь зростання зменшується - на відрізку $X=[0,7 ; 3,25]$ криві «C» $i$ «В» спочатку розходяться, але в міру наближення до «осьової» сходяться. При изьому крива «C» вище кривої «B».

4. П Прогресуюче зменшення чистого доходу більше забезпечених (вище «серединних») верств населення - на відрізку $X=[3,25 ; 5]$ крива «С» нижче кривої $« B »$.

5. Дохід менш забезпечених збільшується в тому ж обсязі, в якому зменшується дохід більш забезпечених - площза фігури, обмеженої кривими «В» $i$ «C» для $X=[0,1 ; 3,25]$ дорівнює площчі фігури, обмежений тими ж кривими для $X$ $=[3,25 ; 5])$.

Однак, не слід забувати того, що, маючи позитивний вплив на розвиток економіки, система прогресивного оподаткування несе в собі ризик ухилення від сплати податків власниками бізнесу, як в частині приховування особистих доходів, одержуваних від бізнесу, так і в частині приховування заробітної плати найманих працівників. Системи прямого i непрямого податкового контролю продемонстрували певну ефективність у питаннях декларування корпоративних доходів (прибуток корпорації і їі розподіл), але в питаннях оплати праці виявилися не дієвими: в ситуації, коли офіційна заробітна плата означає додаткове податкове навантаження, роботодавець, за домовленістю 3 найманим працівником, буде оплачувати його працю, минаючи декларування. I адміністративними методами цю проблему не вирішити. У визначенні оподатковуваного прибутку Корпорації повинен бути застосований механізм, при якому зміна суми декларованої заробітної плати не призводить до зміни суми податків/зборів на заробітну плату і податку на прибуток Корпорації.

\section{Податки і збори на заробітну плату}

Проблема тіньової заробітної плати в тій чи іншій мірі властива для всіх ринкових економік. Податкове навантаження, умови соціального забезпечення (пенсія, медичне страхування тощо), ефективність податкового контролю - це далеко не повний перелік чинників, за якими офіційна і неофіційна заробітна плата стають компромісом фінансових інтересів найманого працівника і роботодавця (власника Корпорації).

I, якщо найманий працівник в цих питаннях вибирає між реальним доходом сьогодні i соціальними гарантіями в майбутньому, то для роботодавця визначальним $є$ зміна податкового навантаження при декларуванні заробітної плати працівника.

Так в разі, якщо декларування заробітної плати призводить до збільшення суми сплачуваних Корпорацією податків, - сума податків на заробітну плату, в тому числі і тих, платником яких формально є найманий працівник, вище суми 
зменшення (за рахунок включення витрат на оплату праці в собівартості) податку на прибуток, - найбільш вірогідною лінією поведінки роботодавця буде знаходження компромісу з найманим працівником у питанні офіційної і тіньової зарплати. I розмір офіційної частини буде залежати від того, наскільки декларована зарплата впливає на рівень соціального забезпечення. У будь-якому випадку, висока ймовірність тіньових виплат: роботодавець буде прагнути домовитися 3 найманим працівником про недекларування частини заробітної плати.

У разі, якщо додаткове податкове навантаження, що виникає при нарахуванні заробітної плати, нівелюється аналогічним зниженням податку на прибуток, роботодавець буде зацікавлений в декларуванні заробітної плати в повному обсязі: у роботодавця відсутня фінансовий інтерес у виплаті тіньової заробітної плати, більш того, подібна виплата може привести до «проблеми з законом».

У разі, якщо декларування заробітної плати призводить до зменшення суми сплачуваних Корпорацією податків, найбільш вірогідною лінією поведінки роботодавця буде: «оформити власників (або близьке оточення власників) Корпорації в якості найманих працівників, і тим самим (за рахунок зменшення оподатковуваного прибутку Корпорації) мінімізувати суму сплачуваних Корпорацією податків».

Як видно, оптимальним, що забезпечує і декларування заробітної плати в повному обсязі, і неможливість знизити суму сплачуваних Корпорацією податків за рахунок декларування заробітної плати, є варіант, при якому «додаткове податкове навантаження, що виникає при нарахуванні заробітної плати, нівелюються аналогічним зниженням податку на прибуток». А це означає, що податок на прибуток Корпорації повинен корелювати з податковим навантаженням на заробітну плату. Тобто, якщо сума податків, що нараховуються на заробітну плату менше фактичного зменшення податку на прибуток, різниця безпосередньо збільшує податок на прибуток Корпорації, і навпаки. У підсумку загальний обсяг сплачуваних Корпорацією податків не залежить від обсягу фонду оплати праці. 


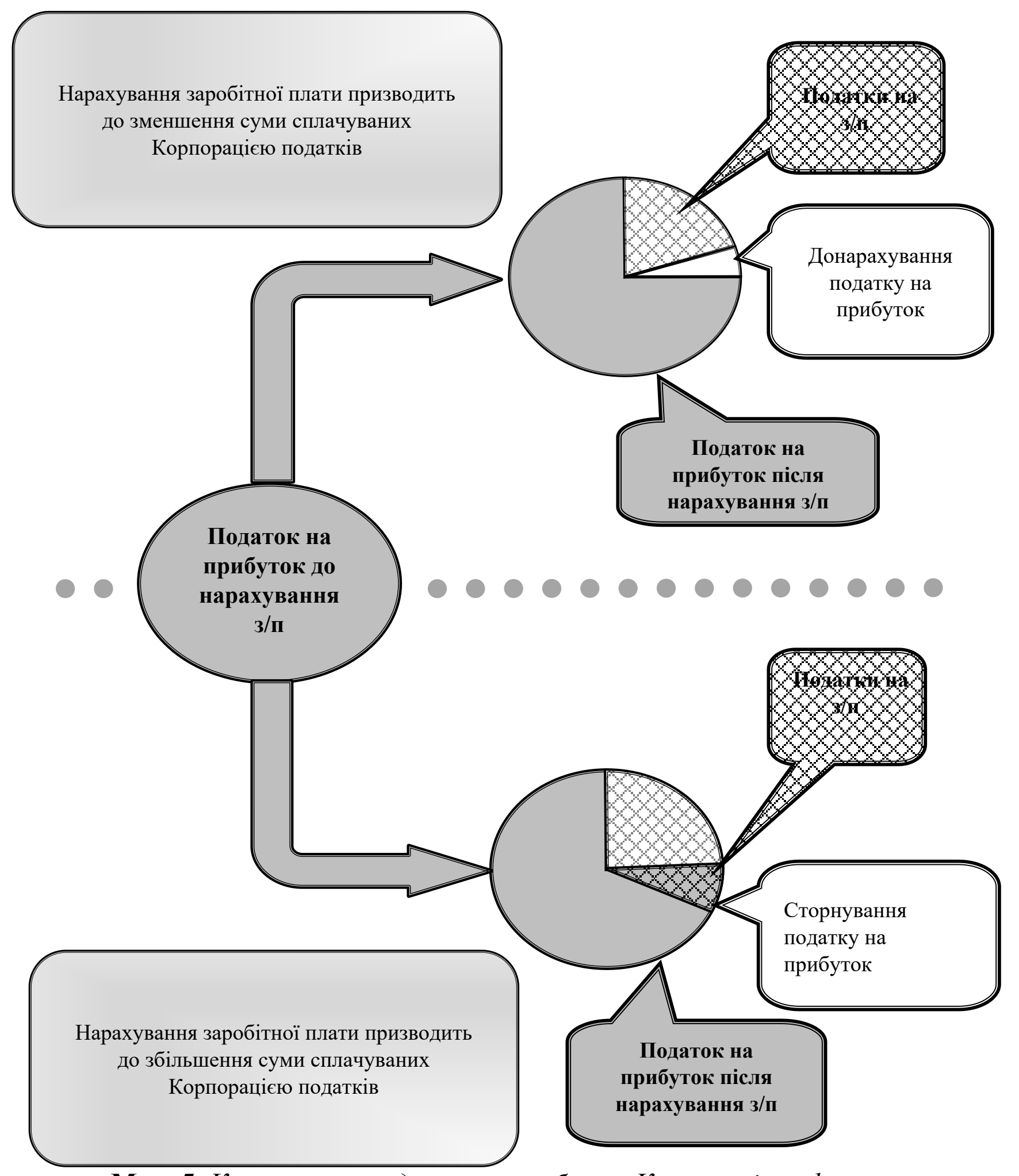

Мал. 5. Коригування податку на прибуток Корпораиії за фактом нарахування заробітної плати.

Додаткове податкове навантаження на «бізнес» в частині «чистої» заробітної плати в Україні становить 24,27\% (ПДФО - 0\%, ССВ - 22,41\%, Військовий збір $1,86 \%$ ) - цим пояснюється, чому в «бізнесі »офіційні зарплати встановлюються на рівні мінімальної.

I, оцінюючи ефект від застосування даного алгоритму, слід говорити не про зростання податкових надходжень, а про детінізацію оплати праці. А враховуючи, 
що детінізація - це практично завжди перехід від готівкового обігу до безготівкового, застосування даного алгоритму зумовить додатковий приплив коштів у банківську систему, що потягне за собою сниження ставки по кредитах/депозитах.

Ще одним податком, що вимагає переосмислення і іншого підходу, є податок на додану вартість (ПДВ) В класичному розумінні ПДВ - це вилучення до бюджету держави частини доданої вартості товару, роботи або послуги, яка створюється на всіх стадіях процесу виробництва товарів, робіт і послуг. Для того щоб зрозуміти в чому економічний сенс даного податку, необхідно розуміти, що є додана вартість, як об'єкт оподаткування, в операціях на внутрішньому ринку. 3 огляду на те, що базою оподаткування ПДВ $є$ різниця між ціною реалізації продукції і ціною придбання проміжних товарів робіт і послуг, додана вартість - це сукупність фонду оплати праці, прибутку Корпорації та податків, що враховуються в собівартості (рентні платежі, податки на нерухомість, податки на рекламу , соціальні / пенсійні збори і т. п.) тобто фактично ПДВ - це додатковий податок на зарплату, на прибуток Корпорації і на кошти, спрямовані на сплату інших податків (податок на податки!). Тому, кажучи про місце ПДВ в системі оподаткування, слід говорити про скасування ПДВ і оптимальне податкове навантаження на доходи фізичних осіб (до числа яких належить і зарплата) і прибуток Корпорацій.

Разом $з$ тим, для експорту/імпорту повинні бути збережені базові принципи оподаткування ПДВ. І пов'язано це 3 розбалансуванням прибутково-видаткової частини сукупної оподатковуваного прибутку економіки при здійсненні зовнішньоторговельних операцій, що проявляється в наступному.

На макроекономічному рівні доходи як об'єкт оподаткування утворюються на стадії реалізації кінцевому споживачеві. В процесі виробництва товарів і послуг оподатковувані доходи компенсуються відповідними витратами: «доходи фізичних осіб - витрати на заробітну плату», «доходи Корпорації-продавця - витрати Корпорації-покупця». Але, коли Корпорацією-продавцем виступає нерезидент (імпорт) на макроекономічному рівні враховується тільки зменшення податкової бази Корпорації-покупця, як результат - зниження дохідної частини державного бюджету; компенсатором даного зниження повинно стати додаткове оподаткування імпорту. При експорті відбувається зворотне: прибуток ( $\underline{\boldsymbol{\mu}}$ вартість товару, що експортується, а саме прибуток) продавця не балансується відповідними витратами покупця. Відповідно прибуток експортера не повинен обкладатися на загальних підставах.

У світлі вищезазначеного, цілком логічним виглядає звільнення від оподаткування прибутку експортерів та оподаткування імпорту за встановленою ставкою податку на прибуток, але ...

Жоден імпортований товар створює в економіці додану вартість, і від того, який товар імпортується, залежить скільки доданої вартості створюється в процесі доведення товару до кінцевого споживача і скільки додатково сплачується бізнесом податків від використання імпортованих товарів в господарському обороті. Так, якщо мова йде про кінцевий продукт (готова продукція), то доданою вартістю буде торгова націнка імпортера плюс вартість транспортних і складських послуг; якщо ж імпортується сировина, то до націнки і послуг додається вартість 
створення нового кінцевого продукту. У ситуації 3 експортом виникає прямо протилежний ефект - експортуючи сировину та матеріали, бізнес, тим самим, зупиняє процес створення нової доданої вартості, отже, «відсікаються» потенційні доходи бюджету від оподаткування даної вартості (щонайменше, податки на заробітну плату).

Таким чином, тема ефективності оподаткування зовнішньої торгівлі не вичерпується питанням «розбалансування» - важливе значення має фактор доданої вартості. I в зв'язку 3 цим, одним 3 інструментів вирішення головного завдання політики держави, а саме зростання доданої вартості в економіці (що тотожне зростанню доходів Держбюджету) стає диференціація ставок оподаткування в залежності від того, до якої групи (кінцевий продукт, проміжний продукт, сировина) відносяться експортовані/імпортовані товари i i яка додана вартість створюється з їх участю, що означає:

- для імпортерів, оподаткування за встановленою ставкою податку на прибуток вартості кінцевого продукту (готова продукція, послуги), застосування понижувальних коефіцієнтів для проміжного продукту (комплектуючі i промислові напівфабрикати), і звільнення від оподаткування, або застосування мінімальної ставки для сировини і матеріалів;

- також для імпортерів, звільнення від оподаткування, або застосування мінімальної ставки для основних виробничих фондів, технологій і т.п. , як виробничої бази генерування нової доданої вартості; в разі подальшої реалізації даної групи товарів - обкладання за встановленою ставкою податку на прибуток неамортизованої вартості;

- для експортерів, звільнення від оподаткування прибутку від реалізації кінцевого корисного продукту (готова продукція, послуги), застосування підвищувальних коефіцієнтів для проміжного продукту (комплектуючі i напівфабрикати) і оподаткування за встановленою ставкою податку прибутку від реалізації сировини і матеріалів.

Приміряючи дану модель оподаткування зовнішньої торгівлі на Україні необхідно слідувати від зворотного: чого не реалізоване або що реалізовано не належним чином, і як це позначилося на економіці.

Імпорт.

Ввезення товару на митну територію України, отримання робіт (послуг) від нерезидента оподатковуються ПДВ за ставкою 20\%, - тобто в певній мірі ( «в певній», так як ставка ПДВ не збігається зі ставкою податку на прибуток 18\%) має місце балансування дохідної частини державного бюджету. У той же час, існуючий порядок, коли «імпортний» ПДВ включається в податковий кредит, а сума ПДВ, що підлягає сплаті, визначасться як різниця між сумою податкового зобов'язання та сумою податкового кредиту, нівелює ефект «диференціації ставок» - в кінцевому підсумку сплачується: «імпортний» ПДВ плюс різниця між ПДВ, нарахованим на реалізаційну вартість і «імпортним» ПДВ. Цим, власне, i пояснюється той факт, що скасування ПДВ на імпорт природного газу, потім повторне його введення не надали будь-якого істотного впливу на розвиток економіки України. У гіршому випадку сплата «імпортного» ПДВ означає тимчасове відволікання оборотних коштів імпортера. 


\section{Експорт.}

Операції з вивезення товарів у режимі експорту, відповідно до положень ПКУ підлягають оподаткуванню за нульовою ставкою. Це означає, що при здійсненні експортних операцій зобов'язання зі сплати ПДВ до бюджету не виникають. А податковий кредит, сплачений постачальникам товарів або послуг при їх придбанні, залишається в повному розпорядженні експортера.

В даному порядку оподаткування становить інтерес «податковий кредит, сплачений постачальникам товарів». Якщо розглядати його (кредит) з точки зору формування податкових зобов'язань, то це ПДВ, сплачений до цього виробниками, постачальниками і т.п. даного товару. Тобто, фактично «виробники, постачальники і т.п.» через Держбюджет фінансують експортера, і для експортера відшкодування ПДВ відбувається двічі: за рахунок коштів покупця-нерезидента (виручка від реалізації) і за рахунок коштів бюджету (відшкодування). Ця пільга повинна була б стимулювати розвиток експортно-орієнтованого виробництва. Разом $з$ тим, високе податкове навантаження, яке спричинило згортання в Україні бізнесу високої доданої вартістю (в тіньовій економіці ведення подібного бізнесу практично неможливо) і відсутність диференціації призвели до того, що дана пільга знайшла застосування в експорті продукції з низькою часткою доданої вартості (продукція сільського господарства, металопрокат). Виробництво ж експортно-орієнтованої продукції високої доданої вартості стало прерогативою державних підприємств (де збитковість діяльності не критично для менеджменту) i одним із способів «заробляння» на Державному бюджеті стало посередництво в експорті виробленої на держпідприємствах продукції, коли навіть при нульовій торговельній націнці експортна операція рентабельна за рахунок відшкодування ПДВ (що було б в принципі неможливо, якби пільга застосовувалася до прибутку експортера).

В результаті система оподаткування в цілому і оподаткування експортноімпортних операцій зокрема вибудовують економіку так, що:

- імпортується «висока додана вартість»: генерування високої доданої вартості для бізнесу менш ефективно, ніж перепродаж уже готової продукції, що імпортується.

- експортується «низька додана вартість»: використання пільги з експорту певною мірою компенсує «податкові збитки» від генерування доданої вартості;

- реалізуються корупційні схеми збагачення за рахунок Державного бюджету: заволодіння ПДВ, сплаченим державними підприємствами.

\section{Оподаткування транскордонного руху капіталів.}

Розглядаючи тему зовнішньоекономічної діяльності не можна обійти увагою і транскордонний рух капіталів. При тому, що операції з капіталом, в разі, якщо ці операції не є виключним видом діяльності, не впливають на оподатковуваний прибуток економіки, експорт/імпорт капіталу призводить до зміни фінансової бази генерування доданої вартості. Наприклад, альтернативою інвестування національною Корпорацією коштів за кордон $є$ придбання товару у вітчизняного виробника, що означає «нова додана вартість» (у продавця), тобто інвестуванням коштів за кордон фактично знижується рівень доданої вартість в економіці. Навпаки, іноземні інвестиції, якщо вони спрямовуються на придбання товарів на внутрішньому ринку, обумовлюють зростання доданої вартість в економіці - навіть 
якщо за рахунок даних інвестицій придбаваються товари на зовнішніх ринках, це призводить до зростання дохідної частини Державного бюджету (оподаткування імпорту). Тому, інвестування національною Корпорацією коштів за кордон, як об'єкт оподаткування, повинно бути прирівняне до імпорту кінцевого корисного продукту (по суті, це $є$ імпорт корпоративних прав) із застосуванням встановленої ставки податку на прибуток, а іноземні інвестиції - до експорту кінцевого корисного продукту і до оподатковуваного прибутку об'єкта інвестування повинні бути застосовані пільги експортера кінцевого корисного продукту, тобто база оподаткування повинна бути зменшена на суму інвестицій.

Певною мірою $є$ неоднозначним питання про оподаткування дивідендів, нарахованих на користь нерезидентів.

3 одного боку, нерезиденти, як кінцеві власники доходів Корпорації, повинні обкладатися нарівні з кінцевими власниками-резидентами, тобто за прогресивною ставкою оподаткування.

3 іншого боку, до низьких доходів нерезидентів (що цілком ймовірно, коли номінальними власниками Корпорації є ряд підконтрольних реальному власникунерезиденту пов'язаних осіб) повинна бути застосована знижена ставка оподаткування і результатом буде перерозподіл доходів високозабезпечених груп резидентів на користь нерезидентів.

Тому компромісним виглядає варіант, коли:

по-перше, до доходів нерезидентів застосовується прогресивна шкала оподаткування, але тільки в частині підвищених (більше оптимальної) ставок;

по-друге, в рамках певної Корпорації, ставка оподаткування (за шкалою доходів) визначається не по доходам окремого власника-нерезидента, а за сукупним доходом всіх власників-нерезидентів..

\section{Концептуальна модель}

Нові механізми оподаткування, новий підхід до визначення об'єктів і суб'єктів оподаткування, в певній мірі, нова філософія оподаткування, все це мало єдину концептуальну основу: існує оптимальний рівень податкового навантаження на сукупний дохід економіки, при якому податкові надходження досягають максимуму, i існує оптимальний розподіл податкового навантаження між кінцевими бенефіціарами доходів економіки, що забезпечує зростання доданої вартості національного виробництва (прогресивне оподаткування, що підвищує рівень споживання низькодохідних верств населення за рахунок зниження рівня накопичення високоприбуткових верств населення) i експортного потенціалу країни (податкове регулювання зовнішньоекономічної діяльності, що стимулює зростання доданої вартості та інвестиційної привабливості економіки).

I в рамках даної концепції вибудовується наступна архітектура системи оподаткування. 


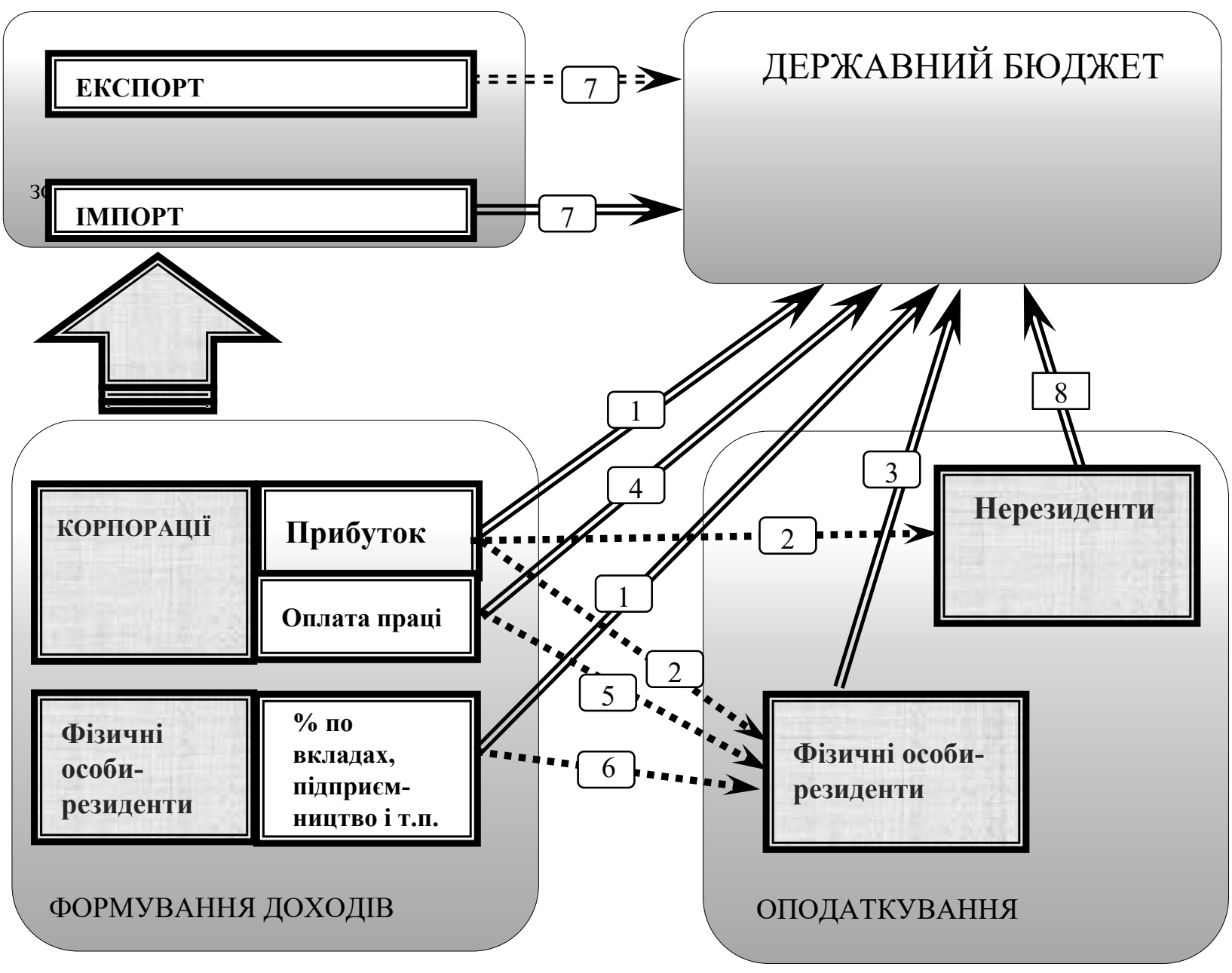

Сукупний дохід економіки ділиться на три группи:

1. Прибуток Корпорацій - оподатковується за оптимальною ставкою (1).

2. Доходи фізичних осіб-резидентів - оподатковуються за прогрессивною (3)

3. Доходи нерезидентів - оподатковуються за прогресивною шкалою, в частині підвищених (більше оптимальної) ставок (8)

\section{Доходи, що генеруються бізнесом.}

Прибуток Корпораиій

Спочатку, отриманий Корпорацією прибуток оподатковується за оптимальною ставкою (1).

За фактом отримання Власником доходу від бізнесу (2) розподілений прибуток Корпорації стає об'єктом оподаткування, але вже як частина сукупного доходу Власника Корпорації.

Сума податку, що підлягає сплаті Власником Корпорації визначається за прогресивною шкалою оподаткування (базовим елементом якої $є$ оптимальна податкове навантаження), при цьому, дана сума зменшується на сплачений Корпорацією податок на прибуток. В результаті, якщо фактичні доходи Власника за прогресивною шкалою оподатковуються за ставкою нижче, ніж оптимальна, Власник отримує з бюджету відшкодування податку на прибуток (3), і навпаки, якщо вище, Власник доплачує за прогресивною ставкою $(3,8)$. Таким чином податкове навантаження на сукупний дохід економіки балансується навколо оптимальної ставки. 


\section{Оплата праиі.}

Застосування особливого алгоритму визначення податкових зобов'язань при виплаті заробітної плати обумовлює наступне: в доданої вартості бізнесу сумарне значення податку на прибуток Корпорації та податку на заробітну плату балансується на рівні оптимальної ставки оподаткування (4).

\section{Оподаткування доходів кінцевих бенефіціарів-резидентів.}

Розподілені між кінцевими бенефіціарами доходи $(2,5,6)$ оподатковуються за прогресивною шкалою (3), i, з огляду на алгоритм визначення параметрів прогресивного оподаткування, в результаті сукупний дохід економіки (в частині резидентів) оподатковується за оптимальною ставкою.

\section{Зовнішньоекономічна діяльність.}

Диференціація ставок оподаткування експортно-імпортних операцій (7) в залежності від ступеня участі об'єкта експорту/імпорту в створенні нової доданої вартості стає ще одним елементом оптимального оподаткування.

Висновки. В Україні базовою податкової доктриною була і залишається «оподаткування бізнесу, а не Власників бізнесу». I, якщо низка криз, падіння реального виробництва і перетворення країни на сировинний придаток передових економік змусили владу переглянути свої погляди на рівень податкового навантаження і почати робити кроки щодо ії зниження (зменшення ставки податку на прибуток з 25\% до $18 \%$, зменшення розміру нарахувань на фонд оплати праці 3 $34,7 \%$ до 22\%), при цьому не маючи чітких орієнтирів оптимальності, то питання розподілу податкового навантаження залишилися поза іiі (влади) уваги: пропорційна система оподаткування фізичних осіб, спрощена система оподаткування, відмінності в податковому навантаженні як по суб'єктах, так і по об'єктах оподаткування - все це обумовило незбалансованість податкового навантаження.

Сьогодні оподаткування в Україні далеко від оптимальності як в частині податкового навантаження, так тим більше в частині розподілу податкового навантаження і назріле системне реформування - це:

1. Скасування внутрішнього ПДВ і встановлення ставки податку на прибуток юридичних осіб на рівні оптимальної.

Звісно, запропонована в даній роботі методика визначення оптимального податкового навантаження не $\epsilon$ "істиною в останній інстанції», а лише одна 3 точок зору на дану проблему. Разом з тим, спочатку необхідно перекласти податкове навантаження 3 внутрішнього ПДВ на Податок на прибуток, і згодом, оцінюючи ефект, знижувати ставку податку на прибуток до рівня оптимальної.

2. Прогресивне оподаткування доходів фізичних осіб на підставі поданої в роботі моделі. Базовим елементом при визначенні параметрів прогресивно оподаткування повинна бути діюча ставка податку на прибуток.

3. Застосування представленого в роботі алгоритму оподаткування дивідендів.

4. Застосування представленого в роботі алгоритму коригування податку на прибуток юридичних осіб при нарахуванні заробітної плати.

5. Диференціювання ставок ПДВ в оподаткуванні зовнішньоторговельних операцій. 
6. Застосування представленого в роботі алгоритму оподаткування транскордонного руху капіталу.

7. Скасування єдиного податку (зниження максимально допустимого порогу суми річного доходу).

8. У визначенні валових (податкових) витрат повернення до редакції норм ПКУ діяли до 2015 року (виробничі / невиробничі). Діючі на сьогодні правила визначення витрат (П(С)БО 16) дають можливість підприємству зменшувати оподатковуваний прибуток, здійснюючи невиробничі витрати, в тому числі i на користь власника.

9. Впровадження системи непрямого адміністрування доходів, в тому числі і обов'язкового декларування майнового стану фізичними особами.

I такий комплекс реформ наблизить податкову систему до оптимальної і дозволить змінити ї спрямованість від «виключно фіскальної» до «також стимулюючої».

В статті не розглядається питання обов'язкових пенсійних внесків (предмет окремого дослідження), але, на думку автора, в концепиії оптимальності податкової системи обов'язкове пенсійне страхування будується на наступних базових принциипах:

- обов'язкові пенсійні внески є частиною податку на доходи фізичних осіб;

- у визначенні розміру належної пенсї застосовується зворотна прогресія по аналогії з прогресивним оподаткування, тільки з точністю до навпаки: на нижній сходинці доходу - максимальний відсоток відрахування, 3 кожною наступною сходинкою - зниження відсотка, $i$ мінімальне (близьке до нуля) відрахування на верхньому щзаблі.

\section{Лimepamypa:}

1. Налоговая реформа в Украине и республике Беларусь: аналитические исследования: монография / [под ред. В. Г. Барановой, О. Е. Дубовик, Е. Ф. Киреевой]. - Харьков: Издательство «Диса плюс», 2016. - 240 с

2. Економічна статистика / Вартість основних засобів у 2010-2017 роках [Електронний pecypc]. - Режим доступу: http://www.ukrstat.gov.ua/

3. Київський міжнародний інститут соціології / Прес-релізи та звіти/ Тіньова економіка в Україні. Результати дослідження 2019 року. [Електронний ресурс]. - Режим доступу: http://kiis.com.ua/?lang=ukr\&cat=reports\&id=897\&page=1\&fbclid=IwAR1GSrnl614vk1GZE4QR9yek Dt_C_NMIXJ-eA0mWArZpSC3DsCgwPsZ7unw

4. Економічна статистика / Прямі інвестиції (акціонерний капітал) (2010-2018) [Электронный ресурс]. - Режим доступа: http://www.ukrstat.gov.ua/

5. Економічна статистика / Власний капітал підприємств за видами економічної діяльності станом на 31 грудня 2017 року; Фінансові результати підприємств до оподаткування за видами промислової діяльності у 2017 році [Електронний ресурс]. - Режим доступу: http://www.ukrstat.gov.ua/

6. Процентні ставки за кредитами та депозитами. Цінні папери резидентів. Індекс ПФТС [Електронний ресурс]. - Режим доступу: https://bank.gov.ua/ua/statistic/sector-financial/data-sectorfinancial\#2fs

7. Річний звіт про виконання Державного бюджету України за 2019рік [Електронний ресурс]. - Режим доступу:

https://www.treasury.gov.ua/ua/file-storage/richnij-zvit-pro-vikonannya-derzhavnogo-byudzhetuukrayini-za-2019-rik 
8. Економічна статистика / Національні рахунки [Електронний ресурс]. - Режим доступу: http://www.ukrstat.gov.ua/

\section{References:}

1. Baranova, V.G., Dubovik, O.E., Kireeva, E.F. (2016). Nalogovaya reforma $v$ Ukraine $i$ respublike Belarus [Tax reform in Ukraine and the Republic of Belarus]. Kharkiv: Disa plyus [in Russian].

2. Ekonomichna statystyka / Vartist osnovnykh zasobiv u 2010-2017 rokakh [Economic statistics / Value of fixed assets in 2010-2017]. www.ukrstat.gov.ua. Retrieved from http://www.ukrstat.gov.ua/ [in Ukrainian].

3. Tinova ekonomika v Ukraini. Rezultaty doslidzhennia 2019 roku [Shadow economy in Ukraine. The results of the 2019 study]. (2019). kiis.com.ua. Retrieved from http://kiis.com.ua/?lang=ukr\&cat=reports\&id=897\&page=1\&fbclid=IwAR1GSrnl614vk1GZE4QR9yek Dt_C_NMIXJ-eA0mWArZpSC3DsCgwPsZ7unw [in Ukrainian].

4. Ekonomichna statystyka / Priami investytsii (aktsionernyi kapital) (2010-2018) [Economic statistics / Direct investment (share capital) (2010-2018)]. www.ukrstat.gov.ua. Retrieved from http://www.ukrstat.gov.ua/ [in Ukrainian].

5. Finansovi rezultaty do opodatkuvannia velykykh ta serednikh pidpryiemstv za vydamy ekonomichnoi diialnosti. Arkhiv 2017 [Financial results before taxation of large and medium enterprises by type of economic activity. Archive 2017]. www.ukrstat.gov.ua. Retrieved from http://www.ukrstat.gov.ua/operativ/operativ2017/fin/fin_rez/fr_ed/fr_ed_u/arh_fr_edo2017_u.htm [in Ukrainian].

6. Protsentni stavky za kredytamy ta depozytamy. Tsinni papery rezydentiv. Indeks PFTS [Interest rates on loans and deposits. Securities issued by residents. PFTS index]. (n.d.) bank.gov.ua. Retrieved from https://bank.gov.ua/files/4-Financial_markets.xlsx [in Ukrainian].

7. Richnyi zvit pro vykonannia Derzhavnoho biudzhetu Ukrainy za 2019 rik [Annual report on the implementation of the State Budget of Ukraine for 2019]. (n.d.). treasury.gov.ua. Retrieved from https://www.treasury.gov.ua/ua/file-storage/richnij-zvit-pro-vikonannya-derzhavnogo-byudzhetuukrayini-za-2019-rik [in Ukrainian].

8. Ekonomichna statystyka / Natsionalni rakhunky [Economic statistics / National accounts]. www.ukrstat.gov.ua. Retrieved from http://ukrstat.gov.ua/operativ/menu/menu_u/nac_r.htm [in Ukrainian]. 